\title{
EFFECT OF DECOMPOSITION OF LEAF LITTER ON AVAILABLE NITROGEN AND SULPHUR IN SIMAROUBA GLAUCA AND CALOPHYLLUM INOPHYLLUM AGRO-FORESTRY TREE SPECIES
}

PRASANNA KUMARA. M, GIRIPRASAD. M. H, GOPIKA. M. H, NAGARAJU \& HATTAPPA. S

University of Agricultural Sciences, GKVK, Bengaluru, Karnataka, India

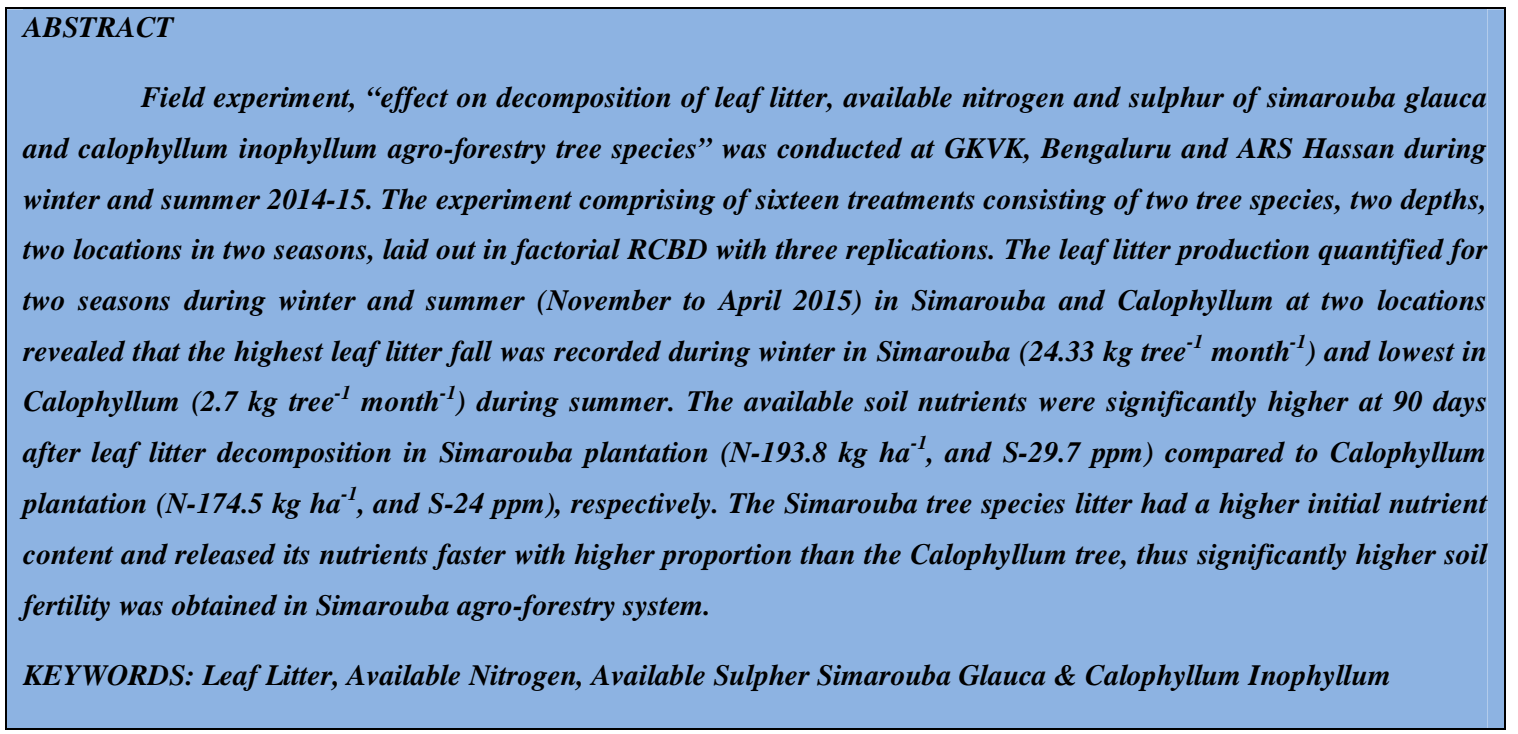

Received: May 25, 2017; Accepted: Jun 19, 2017; Published: Ju1 10, 2017; Paper Id.: IJASRAUG201720

\section{INTRODUCTION}

The importance of litter production in forest ecosystems has long been recognized, because most of the organic matter produced by plants through photosynthesis is returned to soil as litter. Litter fall may be a seasonal or a continuous process and represents one of the most important pathways for the transfer of energy and material. These two processes are determining to a large extent the structural and functional features of the ecosystems. This litter fall is a key process in determining the nutrient cycling of forest ecosystems. The magnitude of leaf litter fall regulates the rate of soil respiration and soil organic carbon content, thus maintaining soil fertility. The decomposition is regulated by soil organisms, environmental conditions and the chemical nature of the litter. The decay of organic matter returned to soil through litter fall is an important source of inorganic ions for plant uptake and the nutrients are released from decaying organic matter by physical and biological processes (Baker and Attiwill, 1985). The decomposition of leaf litter plays an important role in maintaining soil fertility in terms of nutrient cycling and formation of soil organic matter (Guendehou et al. 2014).

Agro-forestry systems include both traditional and modern land-use systems, where, trees are managed together with crops and animal production systems in agricultural settings. Agro-forestry is practiced in both irrigated and rain fed conditions where it produces food, fuel, fodder, timber, fertilizer and fiber, contributes to food, nutritional and ecological security, sustains livelihoods, alleviates poverty and promotes productive and 
resilient cropping and farming environments. Agro-forestry also has the potential to enhance ecosystem services through carbon storage, prevention of deforestation, biodiversity conservation and soil and water conservation. In addition, when strategically applied on a large scale with appropriate mix of species. Agro-forestry enables agricultural land to with stand extreme weather events viz., floods, droughts and climate change. A major role for agro forestry is emerging in the domain of environmental services. Agro-forestry is known to have the potential to mitigate the climate change effects through microclimate moderation and natural resources conservation in the short run and through carbon sequestration in long run. Agro-forestry species are known to sequester carbon in below ground biomass, as much as in the primary forests and far greater than the crop and grass land systems.

Growing trees in agro-forestry and plantations provides lot of litter, which improves soil nutrients upon decomposition. Hence, an experiment was contemplated to know the "Studies on decomposition of leaf litter and nutrient dynamics of Simarouba glauca and Calophyllum inophyllum Agro-forestry tree species" duringwinter and summer seasons in the eastern dry zone at All India Co-ordinated Research Project (AICRP), Agro-forestry, UAS, GKVK, Bengaluru and transition zone at biofuel, park Hassan with the specific objective, To estimate the nutrient status in soils of Simarouba and Calophyllum plantations.

\section{MATERIAL AND METHODS}

Field investigations were carried out during 2014 November to assess the "effect on decomposition of leaf litter, available nitrogen and available sulpher of simarouba glauca and calophyllum inophyllum agro-forestry tree species" in Eastern Dry Zone at All India Co-ordinated Research Project (AICRP) Agro-forestry UAS, GKVK, Bengaluru and Transition Zone at biofuel park Hassan during the year 2014-15. The details of the materials used and the methods employed are discussed in this chapter.

The soil of the experimental site was red sandy loam with gravelly texture in All India Co-ordinated Research Project (AICRP), Bengaluru. Composite samples were drawn from the experimental site.

Initial chemical characteristics of Simarouba and Calophyllum leaf litter revealed that, the Simarouba leaf has

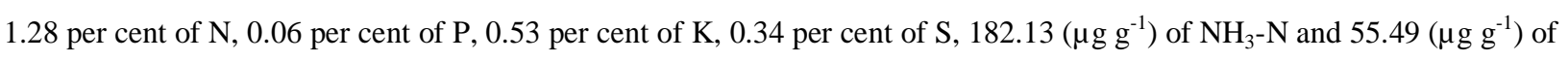
$\mathrm{NO}_{3}-\mathrm{N}$. Whereas, in Calophyllum leaf contains 0.73 per cent of $\mathrm{N}, 0.048$ per cent of $\mathrm{P}, 0.85$ per cent of $\mathrm{K}, 0.28$ per cent of $\mathrm{S}, 130.14\left(\mu \mathrm{g} \mathrm{g}^{-1}\right)$ of $\mathrm{NH}_{3}-\mathrm{N}$ and $35.08\left(\mu \mathrm{g} \mathrm{g}^{-1}\right)$ of $\mathrm{NO}_{3}-\mathrm{N}$, respectively at both the sites.

The experiment has been laid out as per Factorial Randomized Complete Block Design (FRCBD) by considering 2 tree species and 2 depths in 2 locations at 2 seasons with 3 replications. The details of the experiment as follows,

\section{Table 1}

\begin{tabular}{|c|c|c|c|c|}
\hline Treatments & \multicolumn{2}{|c|}{ Depths } & & Locations \\
\hline $\mathrm{T}_{1}$ & \multicolumn{2}{|c|}{$\mathrm{D}_{1}(5 \mathrm{~cm})$} & $\mathrm{L}_{1}$ & (Bengaluru) \\
\hline (Simarouba) & \multicolumn{2}{|c|}{$\mathrm{D}_{1}(5 \mathrm{~cm})$} & $\mathrm{L}_{2}$ & (Hassan) \\
\hline & \multicolumn{2}{|c|}{$\mathrm{D}_{2}(10 \mathrm{~cm})$} & $\mathrm{L}_{1}$ & (Bengaluru) \\
\hline & \multicolumn{2}{|c|}{$\mathrm{D}_{2}(10 \mathrm{~cm})$} & $\mathrm{L}_{2}$ & (Hassan) \\
\hline $\mathrm{T}_{2}$ & $\mathrm{D}_{1}$ & $(5 \mathrm{~cm})$ & $\mathrm{L}_{1}$ & (Bengaluru) \\
\hline \multirow[t]{3}{*}{ (Calophyllum) } & $\mathrm{D}_{1}$ & $(5 \mathrm{~cm})$ & $\mathrm{L}_{2}$ & (Hassan) \\
\hline & D2 & $(10 \mathrm{~cm})$ & L1 & (Bengaluru) \\
\hline & $\mathrm{D}_{2}$ & $(10 \mathrm{~cm})$ & $\mathrm{L}_{2}$ & (Hassan) \\
\hline
\end{tabular}


The total nitrogen in samples was determined by semi micro kjeldhal method as per the procedure outlined by Jackson (1973), using Gerhardt auto analyzer. Sample (0.5 g) was taken in digestion tubes and six $\mathrm{ml}^{\text {of }} \mathrm{H}_{2} \mathrm{SO}_{4}$ was added to which two g of digestion mixture (potassium sulphate, copper sulphate and selenium in the ratio of 100:20:1) was added and kept in the Gerhardt digestion unit for 1 hour 30 minutes at $350^{\circ} \mathrm{C}$. After the digestion was over, the contents in the tubes were cooled and $\mathrm{NH}_{3}$ was distilled and trapped in $25 \mathrm{ml}$ of 4 per cent boric acid under alkaline conditions using 40 per cent $\mathrm{NaOH}$ in Gerhardt vapodest-20. The distillate was titrated against $0.05 \mathrm{~N} \mathrm{H}_{2} \mathrm{SO}_{4}$ using a mixed indicator $(0.1 \mathrm{~g}$ bromo cresol green $+0.07 \mathrm{~g}$ of methyl red in $100 \mathrm{ml}$ ethanol) till the distillate turned blue. The volume of the acid consumed was recorded. Similarly, a standard solution of $\left(\mathrm{NH}_{4}\right)_{2} \mathrm{SO}_{4}$ containing one $\mathrm{mg} \mathrm{N}$ per ml was distilled and titrated. The amount of $\mathrm{N}$ equivalent to one $\mathrm{ml}$ of $0.05 \mathrm{~N} \mathrm{H}_{2} \mathrm{SO}_{4}$ was calculated. The amount of $\mathrm{N}$ in the sample was found out by multiplying the volume of acid consumed and $\mathrm{N}$ equivalent to one $\mathrm{ml}$ of $0.05 \mathrm{~N} \mathrm{H}_{2} \mathrm{SO}_{4}$. The results are expressed in $\mu \mathrm{g} \mathrm{g}^{-1}$ of sample.

Titre value $\times \mathrm{N}$ of $\mathrm{H}_{2} \mathrm{SO}_{4} \times 0.014 \times$ Dilution factors

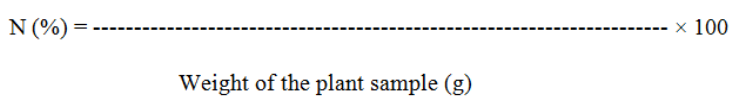

The available sulphur was determined by extracting the soil with 0.15 per cent $\mathrm{CaCl}_{2} \cdot 2 \mathrm{H}_{2} \mathrm{O}$ solution, and extracted $\mathrm{S}$ was quantified by turbidometric method using a spectrophotometer at $420 \mathrm{~nm}$ wave length (Williams and Steinbergs, 1959).

Graph ppm $\times$ Volume of extract $\times$ Volume Made

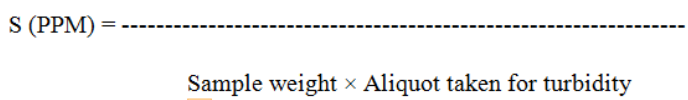

Data recorded on various characters were subjected to analysis of variance. Analysis of different Agro-forestry systems were assessed in comparison with tree species, soil depths, locations with seasons due to the interactions under Simarouba and Calophyllum tree species, making use of contrast method of statistical analysis, as given by Rangaswamy (2010). The level of significance used in ' $F$ ' and ' $t$ ' tests were at $\mathrm{P} \leq 0.05$, critical difference values were calculated wherever the ' $F$ ' test was found to be significant.

\section{EXPERIMENTAL RESULTS}

The results of the field experiment conducted during winter and summer season 2014-15 to investigate the "effect on decomposition of leaf litter, available nitrogen and sulpher of simarouba glauca and calophyllum inophyllum agroforestry tree species" under field conditions in an area of Eastern Dry Zone at AICRP Agro-forestry UAS, GKVK, Bengaluru and Transition Zone at bio-fuel park Hassan. The results thus obtained are presented in this chapter.

\section{Available Soil Nitrogen $\left(\mathrm{Kg} \mathrm{Ha}^{-1}\right)$ At 30, 60 and 90 Days After Leaf Litter Decomposition as Influenced by Soil Depth, Seasons and Locations of Trees Under Agro-Forestry System}

The available $\mathrm{N}$ in soil at $\mathbf{3 0}$ days, after leaf litter decomposition recorded significantly higher $\left(153.45 \mathrm{~kg} \mathrm{ha}^{-1}\right)$ during winter as compared to summer $\left(144.13 \mathrm{~kg} \mathrm{ha}^{-1}\right)$. Similarly, available soil $\mathrm{N}$ recorded showed significant differences at two different soil depths of leaf litter decomposition. Litter decomposition at $5 \mathrm{~cm}$ depth recorded significantly higher available soil $\mathrm{N}\left(154.59 \mathrm{~kg} \mathrm{ha}^{-1}\right)$ as compared to a depth of $10 \mathrm{~cm}\left(142.98 \mathrm{~kg} \mathrm{ha}^{-1}\right)$. 
The locations of agro-forestry system also have significant difference in available $\mathrm{N}$. The highest available $\mathrm{N}$ was recorded at Bengaluru (152.33 $\left.\mathrm{kg} \mathrm{ha}^{-1}\right)$, and the lowest was recorded at Hassan $\left(145.24 \mathrm{~kg} \mathrm{ha}^{-1}\right)$. Among the tree species, Simarouba recorded the highest $\mathrm{N}$ content $\left(163.75 \mathrm{~kg} \mathrm{ha}^{-1}\right)$ as compared to Calophyllum (133.82 $\left.\mathrm{kg} \mathrm{ha}^{-1}\right)$. The interactions also recorded significant differences in $\mathrm{N}$ content. The $\mathrm{N}$ content due to the interaction effects of seasons with tree species the highest $\mathrm{N}$ content of $171.02 \mathrm{~kg} \mathrm{ha}^{-1}$ was recorded during winter in Simarouba agro-forestry system. However, the least $\mathrm{N}$ content was recorded $\left(131.76 \mathrm{~kg} \mathrm{ha}^{-1}\right)$ during summer in Calophyllum agro-forestry system.

Available $\mathrm{N}$ content of soil at different depths with seasons also showed significant difference. Wherein, the highest $\mathrm{N}$ content $\left(158.37 \mathrm{~kg} \mathrm{ha}^{-1}\right.$ ) was recorded at $5 \mathrm{~cm}$ depth during winter, followed by summer, at a depth of $10 \mathrm{~cm}$ (137.44 $\mathrm{kg} \mathrm{ha}^{-1}$ ). The $\mathrm{N}$ content at different locations with season also recorded significant difference. Wherein, the highest value (156.16 $\mathrm{kg} \mathrm{ha}^{-1}$ ) was recorded during winter at Bengaluru, followed by Hassan during summer (139.75 kg ha-1). Available $\mathrm{N}$ content of soil at different depths with tree speciesrecorded significant differences. The highest $\mathrm{N}$ content was recorded at $5 \mathrm{~cm}$ depth $\left(173.93 \mathrm{~kg} \mathrm{ha}^{-1}\right)$ in Simarouba, followed by Calophyllum at a depth of $10 \mathrm{~cm}\left(132.39 \mathrm{~kg} \mathrm{ha}^{-1}\right)$. Available $\mathrm{N}$ content of soil recorded at different locations with tree species also recorded significant differences. The highest $\mathrm{N}$ was recorded (169.98 $\left.\mathrm{kg} \mathrm{ha}^{-1}\right)$ in Simarouba at Bengaluru, followed by Hassan in Calophyllum (132.95 kg ha $\left.{ }^{-1}\right)$. Available $\mathrm{N}$ in soil recorded showedsignificant difference in different locations. The highest $\mathrm{N}$ content was recorded in Bengaluruat $5 \mathrm{~cm}$ depth $\left(159.02 \mathrm{~kg} \mathrm{ha}^{-1}\right)$, and the lowest in Hassan at $10 \mathrm{~cm}$ depth $\left(140.32 \mathrm{~kg} \mathrm{ha}^{-1}\right)$.

Significantly, higher available $\mathrm{N}$ was recorded in Simarouba with interaction effect of tree species, depths with seasons. The highest $\mathrm{N}$ content was recorded during winter in Simarouba at $5 \mathrm{~cm}$ depth $\left(178.89 \mathrm{~kg} \mathrm{ha}^{-1}\right)$. The lowest available $\mathrm{N}$ was recorded during summer in Calophyllum at $5 \mathrm{~cm}$ depth (132.65 $\mathrm{kg} \mathrm{ha}^{-1}$ ) and least available $\mathrm{N}$ was recorded in Calophyllum at $10 \mathrm{~cm}$ depth $\left(130.88 \mathrm{~kg} \mathrm{ha}^{-1}\right)$ compared to winter. Significantly, higher available $\mathrm{N}$ was recorded in Simarouba due to the interaction effect of tree species, with location and seasons. The highest $\mathrm{N}$ content was recorded during winter in Simarouba at Bengaluru (175.43 $\mathrm{kg} \mathrm{ha}^{-1}$ ). The lowest available $\mathrm{N}$ was recorded during summer in Calophyllum at Bengaluru (132.50 $\left.\mathrm{kg} \mathrm{ha}^{-1}\right)$, and the least was recorded in Calophyllum at Hassan (131.03 kg ha $\left.{ }^{-1}\right)$. Significantly higher available N was recorded in Bengaluru due to the interaction effects of depths, locations with seasons. The highest $\mathrm{N}$ content was recorded during winter in Bengaluru at $5 \mathrm{~cm}$ depth $\left(161.52 \mathrm{~kg} \mathrm{ha}^{-1}\right)$. The lowest available $\mathrm{N}$ was observed in Hassan at 10cm depth (134.39 $\mathrm{kg} \mathrm{ha}^{-1}$ ) during summer. Significantly, higher available $\mathrm{N}$ was recorded in Simarouba due to the interaction effect of tree species, depths with locations. The highest $\mathrm{N}$ content was recorded by Bengaluru in Simarouba at $5 \mathrm{~cm}$ depth (181.59 $\left.\mathrm{kg} \mathrm{ha}^{-1}\right)$. The lowest available $\mathrm{N}$ was recorded by Bengaluru in Calophyllum at $10 \mathrm{~cm}$ depth (132.92 $\left.\mathrm{kg} \mathrm{ha}^{-1}\right)$, and the least available $\mathrm{N}$ was recorded by Hassan in Calophyllum at $10 \mathrm{~cm}$ depth (131.86 $\left.\mathrm{kg} \mathrm{ha}^{-1}\right)$.

The interaction effects were also recorded significant difference in $\mathrm{N}$ due to tree species, depths and locations with seasons. The highest $\mathrm{N}$ content of was recorded during winter season in Simarouba at $5 \mathrm{~cm}$ depth in Bengaluru (183.55 $\left.\mathrm{kg} \mathrm{ha}^{-1}\right)$, followed by Bengaluru in Simarouba at $5 \mathrm{~cm}$ depth $\left(179.62 \mathrm{~kg} \mathrm{ha}^{-1}\right)$ during summer, which were on par with each other. The lowest was recorded by Bengaluru in Calophyllum at $10 \mathrm{~cm}\left(131.56 \mathrm{~kg} \mathrm{ha}^{-1}\right)$, and the lowest available $\mathrm{N}$ was recorded by Hassan in Calophyllum at $10 \mathrm{~cm}$ during summer $\left(130.19 \mathrm{~kg} \mathrm{ha}^{-1}\right)$.

The available soil $\mathrm{N}$ was recorded significant difference at $\mathbf{6 0}$ days, after leaf litter decomposition. The highest $\mathrm{N}$ (176.91 $\mathrm{kg} \mathrm{ha}^{-1}$ ) was recorded during winter as compared to summer (159.72 $\left.\mathrm{kg} \mathrm{ha}^{-1}\right)$. Similarly, available soil $\mathrm{N}$ was significantly different at two different soil depths of soil leaf litter decomposition. Litter decomposition at $5 \mathrm{~cm}$ depth 
recorded significantly higher available soil $\mathrm{N}\left(172.31 \mathrm{~kg} \mathrm{ha}^{-1}\right)$ as compared to $10 \mathrm{~cm}$ depth $\left(164.32 \mathrm{~kg} \mathrm{ha}^{-1}\right)$.

The location of the agro-forestry system also recorded significant differencesin $\mathrm{N}$ content. The $\mathrm{N}$ content at Bengaluru in eastern dry zone was significantly higher $\left(171.20 \mathrm{~kg} \mathrm{ha}^{-1}\right)$ as compared to Hassan $\left(150.68 \mathrm{~kg} \mathrm{ha}^{-1}\right)$ in transition zone.

The available soil $\mathrm{N}$ content at 90 days, after leaf litter decomposition, recordedsignificantly higher (189.27 kg ha ${ }^{1}$ ) during winter as compared to summer $\left(179.08 \mathrm{~kg} \mathrm{ha}^{-1}\right)$. Similarly, available soil $\mathrm{N}$ has shown significant differences at two different soil depths of leaf litter decomposition. The litter decomposition at $5 \mathrm{~cm}$ depth recorded significantly higher available soil $\mathrm{N}$ (190.62 $\left.\mathrm{kg} \mathrm{ha}^{-1}\right)$ as compared to a depth of $10 \mathrm{~cm}\left(177.72 \mathrm{~kg} \mathrm{ha}^{-1}\right)$.

The interaction effects also recorded significant differences in $\mathrm{N}$ content and the $\mathrm{N}$ content due to interaction effects of seasons with trees recorded the highest $\mathrm{N}$ content $\left(200.62 \mathrm{~kg} \mathrm{ha}^{-1}\right)$ during winter in Simarouba agro-forestry system. However, the least $\mathrm{N}$ content was recorded during summer in Calophyllum $\left(171.12 \mathrm{~kg} \mathrm{ha}^{-1}\right)$ agro-forestry system.

The $\mathrm{N}$ content at different depths in different seasons also showed significant differences and the highest $\mathrm{N}$ content $\left(197.96 \mathrm{~kg} \mathrm{ha}^{-1}\right)$ was recorded at $5 \mathrm{~cm}$ depth during winter and the lowest was observed in summer at a depth of 10 $\mathrm{cm}\left(174.87 \mathrm{~kg} \mathrm{ha}^{-1}\right)$.

The $\mathrm{N}$ content due to the interaction effects of tree species, depths and locations in different seasons were also significant. The highest $\mathrm{N}$ content of was recorded during winter in Simarouba at $5 \mathrm{~cm}$ depth in Bengaluru $\left(223.21 \mathrm{~kg} \mathrm{ha}^{-1}\right)$. The lowest was recorded by Bengaluru in Calophyllum $\left(167.36 \mathrm{~kg} \mathrm{ha}^{-1}\right)$ at $10 \mathrm{~cm}$ depth, and the lowest available $\mathrm{N}$ was recorded by Hassan in Calophyllum at $10 \mathrm{~cm}$ depth during summer $\left(164.46 \mathrm{~kg} \mathrm{ha}^{-1}\right)$.

Available Soil Sulphur (Ppm) At 30, 60 and 90 Days After Leaf Litter Decomposition as Influenced by Soil Depth, Seasons and Locations of Trees Under Agro Forestry System

The available $S$ content at $\mathbf{3 0}$ days, after leaf litter decomposition, recorded significantly higher (21.36 ppm) during winter as compared to summer (19.68 ppm). Similarly, available soil S recorded showed significant differences at two different soil depths of leaf litter decomposition. Litter decomposition at $5 \mathrm{~cm}$ depth recorded significantly higher $\mathrm{S}$ (21.16 ppm) as compared to a depth of $10 \mathrm{~cm}(19.88 \mathrm{ppm})$. The location of agro-forestry system also recorded significant difference in S content. The available S at Bengaluru in eastern dry zone was significantly higher (20.94 ppm) as compared to Hassan $(20.10 \mathrm{ppm})$ in transition zone. Among the tree species, Simarouba recorded the highest available $\mathrm{S}$ content of 22.40 ppmas compared to Calophyllum (18.64 ppm). The interactions also recorded significant differences in $\mathrm{S}$ content. The available $\mathrm{S}$ due to the interaction effects of seasons with tree species, the highest $\mathrm{S}$ ( 23.18 ppm) was recorded during winter in Simarouba agro-forestry system. However, the least S was recorded (17.74 ppm) during summer in Calophyllum agro-forestry system.

The available $S$ at $\mathbf{6 0}$ days, after leaf litter decomposition, recorded significantly higher (24.45 ppm) during winter as compared to summer (22.27 ppm). Similarly, available soil S recorded showed significant difference at two different soil depths of leaf litter decomposition. Litter decomposition at $5 \mathrm{~cm}$ depth recorded significantly higher available soil S (24.04 ppm) as compared to a depth of $10 \mathrm{~cm}(22.68 \mathrm{ppm})$. The locations of agro-forestry system also recorded significant difference in S content. The S content at Bengaluru in eastern dry zone was significantly higher (23.88 ppm) as compared to Hassan $(22.84 \mathrm{ppm})$ in transition zone. Among the tree species, Simarouba recorded the highest S content of $26.18 \mathrm{ppm}$ as compared to Calophyllum (20.55 ppm). 
The interactions also recorded significant differences in $S$ content. The available $S$ due to the interaction effects of seasons with trees, the highest $\mathrm{S}$ was recorded with winter in Simarouba (27.48 ppm) agro-forestry system. However, the least S content was recorded during summer in Calophyllum (19.67 ppm) agro-forestry system. The available $\mathrm{S}$ at different depths with season also recorded significant differences. The highest $\mathrm{S}$ was recorded at $5 \mathrm{~cm}$ depth (25.00 ppm) during winter and lowest in summer at a depth of $10 \mathrm{~cm}(21.46 \mathrm{ppm})$.

The interactions were also recorded significant difference in $\mathrm{S}$ content. The available $\mathrm{S}$ due to the interaction effects of tree species, depths and locations with seasons. The highest $\mathrm{S}$ was recorded by Bengaluru during winter in Simarouba at $5 \mathrm{~cm}$ depth (28.71 ppm) followed by Hassan in Simarouba at $5 \mathrm{~cm}$ depth (27.35 ppm) followed by Bengaluru in Simarouba at $10 \mathrm{~cm}$ depth (27.04 ppm) followed by Hassan in Simarouba at $10 \mathrm{~cm}$ depth (26.83 ppm) which were all on par with each other. The lowest S was recorded during summer in Calophyllum at $5 \mathrm{~cm}$ depth in Bengaluru (20.77 ppm) followed by Hassan at $5 \mathrm{~cm}$ depth (19.62 ppm) followed by Bengaluru at $10 \mathrm{~cm}$ depth (19.49 ppm), which were on par with each other. The least available $S$ was recorded by Hassan in Calophyllum at $10 \mathrm{~cm}$ depth (18.79 ppm) during summer.

The available $\mathrm{S}$ at $\mathbf{9 0}$ days, after leaf litter decomposition, recorded significantly higher (28.48 ppm) during winter as compared to summer (25.29 ppm). Similarly, available S recorded showed significant differences at two different soil depths of leaf litter decomposition. Litter decomposition at $5 \mathrm{~cm}$ depth recorded significantly higher available $\mathrm{S}$ (27.54 ppm) as compared to a depth of $10 \mathrm{~cm}(26.23 \mathrm{ppm})$. The location of agro-forestry system also recorded significant differencesin S content. The available $\mathrm{S}$ at Bengaluru in eastern dry zone was significantly higher (27.37 ppm) as compared to Hassan (26.40 ppm) in transition zone. Among the tree species, Simarouba recorded the highest available S (29.77 ppm) as compared to Calophyllum (24.00 ppm).

The interaction effects were also significant due to tree species, depths and locations with seasons. The highest $\mathrm{S}$ was recorded by Bengaluru during winter in Simarouba at $5 \mathrm{~cm}$ depth (32.78 ppm), followed by Hassan in Simarouba at 5 cm depth (31.39 ppm), which were on par with each other. The lowest available $\mathrm{S}$ was recorded by Hassan during summer in Calophyllum at $5 \mathrm{~cm}$ depth $(21.44 \mathrm{ppm})$ and least was recorded by Hassan in Calophyllum at $10 \mathrm{~cm}$ during summer (20.78 ppm).

\section{DISCUSSIONS}

The bulk of organic matter and nutrients goes to the soil in a forest ecosystem through litter fall (Bray and Gorham 1964) and plays a vital role in maintaining the forest productivity. The amount and seasonal pattern of litter fall are important factors determining the recycling of nutrients and maintenance of soil fertility in terrestrial ecosystems (Facelli and Pickett 1991). In view of these facts, an experiment on "effect on decomposition of leaf litter, available nitrogen and sulpher of simarouba glauca and calophyllum inophyllum agro-forestry tree species" was conducted in two locations one at Bangalore, which falls under eastern dry zone and another at Hassan located in transitional zone of Karnataka with the objectives (i) To quantify the seasonal variations in leaf litter fall in Simarouba and Calophyllum plantations (ii) To assess the microbial activity in soils of Simarouba and Calophyllum plantations (iii) To estimate the nutrient status in soils of Simarouba and Calophyllum plantations. The results of the field investigation are discussed in this chapter.

The available $\mathrm{N}$ in soil was significantly higher in Simarouba plantation during winter season at 30,60 and $90^{\text {th }}$ days, after leaf litter decomposition and lowest was recorded in Calophyllum during summer season at both the locations. 
While comparing with both locations, the available soil $\mathrm{N}$ was significantly higher in Bangalore compared to Hassan. Similar trend was recorded by Issac and Nair (2004) on the litter production and nutrient turn over in Ailianthus triphysa in an agro forestry system, and reported that the annual litter production amounted to $5.01 \mathrm{mg} \mathrm{ha}^{-1}$ with maximum litter fall in December - January. Foliage was the major constituent of litter and on an annual basis $83.65 \mathrm{~kg} \mathrm{~N}, 2.34 \mathrm{~kg}$ P and $16.58 \mathrm{~K}$ $\mathrm{kg} \mathrm{ha}^{-1}$ were returned through the litter. Another study to know the improvement in soil nutrient status in Artocarpus hirsutus based agro forestry system shown similar trend. $\mathrm{N}$ contents varied from litter of one tree species to another. The $\mathrm{N}$ concentration of both the study sites was initially declined and later mineralized $\mathrm{N}$ in soil, because high quality residues release nutrients rapidly, while nutrients from low quality residues are initially immobilized, and later are eventually mineralized and become available to crops (Xu and Hirata, 2005).

The available soil sulphur decreased during the process of leaf litter decomposition. The available soil $\mathrm{S}$ was recorded significantly higher in Simarouba plantation during summer season at 30, 60 and $90^{\text {th }}$ days, after leaf litter decomposition and lowest was recorded in Calophyllum during winter season at both locations. The available soil S was recorded highest in Bangalore compared to Hassan. The S concentration of litter was generally low during the wet season. This may be due to increased leaching of S, a mobile element. Das and Ramakrishnan (1985) also observed increased surface wash from intact foliage and increased loss of $\mathrm{S}$ from litter collected in traps during the rainy season. Similar trend was recorded by Kavvadias et al. (2000)

\section{CONCLUSIONS}

The available soil nutrients were significantly higher at 90 days, after leaf litter decomposition in Simarouba plantation (N-193.8 $\mathrm{kg} \mathrm{ha}^{-1}$, and S-29.7 ppm) compared to Calophyllum plantation (N-174.5 kg ha ${ }^{-1}$, and S-24 ppm), respectively. The Simarouba tree species litter had a higher initial nutrient content and released its nutrients faster with higher proportion than the Calophyllum tree thus significantly higher soil fertility was obtained in Simarouba agro-forestry system.

Table 2: Available Soil Nitrogen $\left(\mathrm{kg} \mathrm{ha}^{-1}\right)$ at 30 Days after Leaf Litter Decomposition as Influenced by Soil Depth, Seasons and Locations of Trees Under Agro Forestry System

\begin{tabular}{|c|c|c|c|c|c|c|c|c|c|c|c|c|c|c|c|}
\hline \multirow[t]{2}{*}{ Details } & \multicolumn{5}{|c|}{$\mathbf{L}_{1}$} & \multicolumn{5}{|c|}{$\mathbf{L}_{2}$} & \multicolumn{5}{|c|}{ Pooled } \\
\hline & \multicolumn{3}{|c|}{ T1 } & T2 & Mean & \multicolumn{2}{|c|}{ T1 } & \multicolumn{2}{|c|}{ T2 } & Mean & \multicolumn{2}{|c|}{ T1 } & \multicolumn{2}{|c|}{$\mathrm{T} 2$} & Mean \\
\hline S1D1 & \multicolumn{3}{|c|}{183.55} & 139.48 & 161.52 & \multicolumn{2}{|c|}{174.22} & \multicolumn{2}{|c|}{136.22} & 155.22 & \multicolumn{2}{|c|}{178.89} & \multicolumn{2}{|c|}{137.85} & 158.37 \\
\hline S1D2 & \multicolumn{3}{|c|}{167.31} & 134.28 & 150.80 & \multicolumn{2}{|c|}{158.98} & \multicolumn{2}{|c|}{133.53} & 146.26 & \multicolumn{2}{|c|}{163.15} & \multicolumn{2}{|c|}{133.91} & 148.53 \\
\hline Mean & \multicolumn{3}{|c|}{175.43} & 136.88 & 156.16 & \multicolumn{2}{|c|}{166.60} & \multicolumn{2}{|c|}{134.88} & 150.74 & \multicolumn{2}{|c|}{171.02} & \multicolumn{2}{|c|}{135.88} & 153.45 \\
\hline S2D1 & \multicolumn{3}{|c|}{179.62} & 133.43 & 156.53 & \multicolumn{2}{|c|}{158.33} & \multicolumn{2}{|c|}{131.87} & 145.10 & \multicolumn{2}{|c|}{168.98} & \multicolumn{2}{|c|}{132.65} & 150.81 \\
\hline S2 D & \multicolumn{3}{|c|}{149.42} & 131.56 & 140.49 & \multicolumn{2}{|c|}{138.59} & \multicolumn{2}{|c|}{130.19} & 134.39 & \multicolumn{2}{|c|}{144.01} & \multicolumn{2}{|c|}{130.88} & 137.44 \\
\hline Mean & & 164.5 & & 132.50 & 148.51 & 148.4 & & 131 & & 139.75 & & 6.49 & & .76 & 144.13 \\
\hline D1 & & 181.5 & & 136.46 & 159.02 & 166.2 & & 134 & & 150.16 & & 3.93 & & .25 & 154.59 \\
\hline D2 & & 158.3 & & 132.92 & 145.64 & 148.7 & & 131 & & 140.32 & & 3.58 & & 39 & 142.98 \\
\hline Mean & & 169.98 & & 134.69 & 152.33 & 157.5 & & 132 & & 145.24 & & 3.75 & & .82 & 148.79 \\
\hline Comparison & $\mathrm{S}$ & $\mathrm{T}$ & $\mathrm{D}$ & $\mathrm{L}$ & $\mathrm{S} \times \mathrm{T}$ & \begin{tabular}{l|l}
$\mathrm{S} \times \mathrm{D}$ \\
\end{tabular} & $\mathrm{S} \times \mathrm{L}$ & $\mathrm{T} \times \mathrm{D}$ & $\mathrm{T} \times \mathrm{L}$ & $\mathrm{D} \times \mathrm{L}$ & $\mathrm{S} \times \mathrm{T} \times \mathrm{D}$ & $\mathrm{S} \times \mathrm{T} \times \mathrm{L}$ & $\mathrm{S} \times \mathrm{D} \times \mathrm{L}$ & $\mathrm{T} \times \mathrm{D} \times \mathrm{L}$ & $\mathrm{S} \times \mathrm{T} \times \mathrm{D} \times \mathrm{L}$ \\
\hline $\mathrm{SEm} \pm$ & 0.48 & 0.48 & 0.48 & 0.48 & 0.68 & 0.68 & 0.68 & 0.68 & 0.68 & 0.68 & 0.96 & 1.55 & 0.96 & 0.96 & 1.36 \\
\hline $\mathrm{CD}$ at $5 \%$ & 1.38 & 1.38 & 1.38 & 1.38 & 1.95 & 1.95 & 1.95 & 1.95 & 1.95 & 1.95 & 2.76 & 4.77 & 2.76 & 2.76 & 3.91 \\
\hline
\end{tabular}

Note: $\mathbf{S}_{1}$ : Winter season $\mathbf{D}_{1}$ : Depth at $5 \mathrm{~cm} \mathbf{L}_{1}$ :Agro-forestry Bengaluru $\mathbf{T}_{\mathbf{1}}$ :Simarouba glauca

$\mathbf{S}_{\mathbf{2}}$ : Summer season D2: Depth at $10 \mathrm{~cm} \mathbf{L}_{\mathbf{2}}$ : Bio-fuel park Hassan $\mathbf{T}_{\mathbf{2}}$ : Calophyllum inophyllum 
Table 3: Available Soil Nitrogen $\left(\mathrm{kg} \mathrm{ha}^{-1}\right)$ at 60 Days after Leaf Litter Decomposition as Influenced by Soil Depth, Seasons and Locations of Trees under Agro Forestry System

\begin{tabular}{|c|c|c|c|c|c|c|c|c|c|c|c|c|c|c|c|}
\hline \multirow[t]{2}{*}{ Details } & \multicolumn{5}{|c|}{$\mathbf{L}_{1}$} & \multicolumn{5}{|c|}{$\mathrm{L}_{2}$} & \multicolumn{5}{|c|}{ Pooled } \\
\hline & \multicolumn{3}{|c|}{ T1 } & T2 & Mean & \multicolumn{2}{|c|}{ T1 } & \multicolumn{2}{|c|}{ T2 } & Mean & \multicolumn{2}{|c|}{ T1 } & \multicolumn{2}{|c|}{ T2 } & Mean \\
\hline S1D1 & \multicolumn{3}{|c|}{200.54} & 168.26 & 184.40 & \multirow{2}{*}{\multicolumn{2}{|c|}{194.52}} & \multicolumn{2}{|c|}{162.74} & 178.63 & \multicolumn{2}{|c|}{197.53} & \multicolumn{2}{|c|}{165.50} & 181.52 \\
\hline S1D2 & \multicolumn{3}{|c|}{191.14} & 160.63 & 175.89 & & & \multirow{2}{*}{\multicolumn{2}{|c|}{$\begin{array}{l}154.71 \\
158.73\end{array}$}} & 168.71 & \multicolumn{2}{|c|}{186.92} & \multicolumn{2}{|c|}{157.67} & 172.30 \\
\hline Mean & & 195.8 & & 164.45 & 180.14 & \multicolumn{2}{|c|}{188.61} & & & 173.67 & \multicolumn{2}{|c|}{192.23} & \multicolumn{2}{|c|}{161.59} & 176.91 \\
\hline S2D1 & \multicolumn{3}{|c|}{181.83} & 148.25 & 165.04 & \multicolumn{2}{|c|}{178.59} & \multicolumn{2}{|c|}{143.74} & 161.17 & \multirow{2}{*}{\multicolumn{2}{|c|}{$\begin{array}{l}180.21 \\
160.70\end{array}$}} & \multicolumn{2}{|c|}{146.00} & 163.10 \\
\hline S2 D & \multicolumn{3}{|c|}{174.64} & 144.27 & 159.46 & \multicolumn{2}{|c|}{164.94} & \multicolumn{2}{|c|}{141.51} & 153.23 & & & \multicolumn{2}{|c|}{142.89} & 156.34 \\
\hline Mean & \multicolumn{3}{|c|}{178.24} & 146.26 & 162.25 & \multicolumn{2}{|c|}{171.77} & \multicolumn{2}{|c|}{142.63} & 157.20 & \multicolumn{2}{|c|}{175.00} & & & 159.72 \\
\hline D1 & & 191.1 & & 158.26 & 174.72 & & & & & 169.90 & & 8.87 & & & 172.31 \\
\hline D2 & & 182.8 & & 152.45 & 167.67 & & & & & 160.97 & & 8.36 & & & 164.32 \\
\hline Mean & & 187.0 & & 155.35 & 171.20 & & & & & 165.43 & & 3.61 & & & 168.31 \\
\hline Comparison & $\mathrm{S}$ & $\mathbf{T}$ & D & L & $\mathbf{S} \times \mathbf{T}$ & $\mathbf{S} \times \mathbf{D}$ & $\mathbf{S} \times \mathbf{L}$ & $\mathbf{T} \times \mathbf{D}$ & $\mathbf{T} \times \mathbf{L}$ & $\mathbf{D} \times \mathbf{L}$ & $\mathbf{S} \times \mathbf{T} \times \mathbf{D}$ & $\mathbf{S} \times \mathbf{T} \times \mathbf{L}$ & $\mathbf{S} \times \mathbf{D} \times \mathbf{L}$ & $\mathbf{T} \times \mathbf{D} \times \mathbf{L}$ & $\mathbf{S} \times \mathbf{T} \times \mathbf{D} \times \mathbf{L}$ \\
\hline SEm \pm & 0.60 & 0.60 & 0.60 & 0.60 & 0.85 & 0.85 & 0.85 & 0.85 & 0.85 & 0.85 & 1.20 & 1.81 & 1.20 & 1.20 & 1.69 \\
\hline $\mathrm{CD}$ at $5 \%$ & 1.73 & 1.73 & 1.73 & 1.73 & 2.44 & 2.44 & 2.44 & 2.44 & 2.44 & 2.44 & 3.45 & 5.22 & 3.45 & 3.45 & 4.88 \\
\hline
\end{tabular}

Note: S1: Winter season D1: Depth at 5cm L1:Agro-forestry Bengaluru T1:Simarouba glauca

S2: Summer season D2: Depth at 10cm L2: Bio-fuel park Hassan T2:Calophyllum inophyllum

Table 4: Available Soil Nitrogen $\left(\mathrm{kg} \mathrm{ha}^{-1}\right)$ at 90 Days after Leaf Litter Decomposition as Influenced by Soil Depth, Seasons and Locations of Trees under Agro Forestry System

\begin{tabular}{|c|c|c|c|c|c|c|c|c|c|c|c|c|c|c|c|}
\hline \multirow[t]{2}{*}{ Details } & \multicolumn{5}{|c|}{$\mathrm{L}_{\mathrm{l}}$} & \multicolumn{5}{|c|}{$\mathrm{L}_{2}$} & \multicolumn{5}{|c|}{ Pooled } \\
\hline & \multicolumn{3}{|c|}{$\mathrm{Tl}$} & $\mathrm{T} 2$ & Mean & \multicolumn{2}{|c|}{$\mathrm{Tl}$} & \multicolumn{2}{|c|}{$\mathrm{T} 2$} & Mean & \multicolumn{2}{|c|}{$\mathrm{Tl}$} & \multicolumn{2}{|c|}{$\mathrm{T} 2$} & Mean \\
\hline S1D1 & \multicolumn{3}{|c|}{223.21} & 184.54 & 203.88 & \multicolumn{2}{|c|}{202.83} & \multicolumn{2}{|c|}{181.25} & 192.04 & \multicolumn{2}{|c|}{213.02} & \multicolumn{2}{|c|}{182.90} & 197.96 \\
\hline S1D2 & \multicolumn{3}{|c|}{195.28} & 175.25 & 185.27 & \multicolumn{2}{|c|}{181.14} & \multicolumn{2}{|c|}{170.62} & 175.88 & \multicolumn{2}{|c|}{188.21} & \multicolumn{2}{|c|}{172.94} & 180.57 \\
\hline Mean & \multicolumn{3}{|c|}{209.25} & 179.90 & 194.57 & \multicolumn{2}{|c|}{191.99} & \multicolumn{2}{|c|}{175.94} & 183.96 & \multicolumn{2}{|c|}{200.62} & \multicolumn{2}{|c|}{177.92} & 189.27 \\
\hline S2D1 & \multicolumn{3}{|c|}{192.40} & 178.88 & 185.64 & \multicolumn{2}{|c|}{188.11} & \multicolumn{2}{|c|}{173.76} & 180.94 & \multicolumn{2}{|c|}{190.26} & \multicolumn{2}{|c|}{176.32} & 183.29 \\
\hline S2 D & \multicolumn{3}{|c|}{185.50} & 167.36 & 176.43 & \multicolumn{2}{|c|}{182.16} & \multicolumn{2}{|c|}{164.46} & 173.31 & \multicolumn{2}{|c|}{183.83} & \multicolumn{2}{|c|}{165.91} & 174.87 \\
\hline Mean & & 188.95 & & 173.12 & 181.04 & 18. & & & & 177.12 & 18 & & 17. & & 179.08 \\
\hline D1 & & 207.81 & & 181.71 & 194.76 & 195 & & & & 186.49 & 20 & & 179 & & 190.62 \\
\hline $\mathrm{D} 2$ & & 190.39 & & 171.31 & 180.85 & 181 & & & & 174.60 & 18 & & 169 & & 177.72 \\
\hline Mean & & 199.10 & & 176.51 & 187.80 & 188 & & & & 180.54 & 19 & & 17 & & 184.17 \\
\hline Comparison & $\mathrm{S}$ & $\mathrm{T}$ & $\mathrm{D}$ & $\mathrm{L}$ & $\mathrm{S} \times \mathrm{T}$ & SXD & $\mathrm{S} \times \mathrm{L}$ & $T \times D$ & $\mathrm{~T} \times \mathrm{L}$ & $\mathrm{D} \times \mathrm{L}$ & SXTXD & $\mathrm{S} \times \mathrm{T} \times \mathrm{L}$ & $S \times D \times L$ & $\mathrm{~T} \times \mathrm{D} \times \mathrm{L}$ & 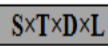 \\
\hline $\operatorname{SEm} \pm$ & 0.70 & 0.70 & 0.70 & 0.70 & 1.99 & 1.99 & 1.99 & 1.99 & 1.99 & 1.99 & 1.41 & 1.12 & 1.41 & 1.41 & 1.99 \\
\hline $\mathrm{CD}$ at $5 \%$ & 2.03 & 2.03 & 2.03 & 2.03 & 2.87 & 2.87 & 2.87 & 2.87 & 2.87 & 2.87 & 4.05 & 3.22 & 4.05 & 4.05 & 5.73 \\
\hline
\end{tabular}

Note: S1: Winter season D1: Depth at 5cm L1:Agro-forestry Bengaluru T1:Simarouba glauca

S2: Summer season D2: Depth at 10cm L2: Bio-fuel park Hassan T2:Calophyllum inophyllum

Table 5: Available Soil Sulphur (ppm) at 30 Days after Leaf Litter Decomposition as Influenced by Soil Depth, Seasons and Locations of Trees Under Agro Forestry System

\begin{tabular}{|c|c|c|c|c|c|c|c|c|c|c|c|c|c|c|c|}
\hline \multirow[t]{2}{*}{ Details } & \multicolumn{5}{|c|}{$\mathrm{L}_{1}$} & \multicolumn{5}{|c|}{$\mathrm{L}_{2}$} & \multicolumn{5}{|c|}{ Pooled } \\
\hline & \multicolumn{3}{|c|}{ T1 } & $\mathrm{T} 2$ & Mean & \multicolumn{2}{|c|}{$\mathrm{Tl}$} & \multicolumn{2}{|c|}{$\mathrm{T} 2$} & Mean & \multicolumn{2}{|c|}{ T1 } & \multicolumn{2}{|c|}{$\mathrm{T} 2$} & Mean \\
\hline S1D1 & \multicolumn{3}{|c|}{24.68} & 20.47 & 22.58 & \multicolumn{2}{|c|}{23.73} & \multicolumn{2}{|c|}{19.78} & 21.76 & \multicolumn{2}{|c|}{24.21} & \multicolumn{2}{|c|}{20.13} & 22.17 \\
\hline S1D2 & \multicolumn{3}{|c|}{22.28} & 19.61 & 20.95 & \multicolumn{2}{|c|}{22.03} & \multicolumn{2}{|c|}{18.29} & 20.16 & \multicolumn{2}{|c|}{22.16} & \multicolumn{2}{|c|}{18.95} & 20.55 \\
\hline Mean & \multicolumn{3}{|c|}{23.48} & 20.04 & 21.76 & \multicolumn{2}{|c|}{22.88} & \multicolumn{2}{|c|}{19.04} & 20.96 & \multicolumn{2}{|c|}{23.18} & \multicolumn{2}{|c|}{19.54} & 21.36 \\
\hline S2D1 & \multicolumn{3}{|c|}{22.68} & 18.86 & 20.77 & \multicolumn{2}{|c|}{21.58} & \multicolumn{2}{|c|}{17.49} & 19.54 & \multicolumn{2}{|c|}{22.13} & \multicolumn{2}{|c|}{18.18} & 20.15 \\
\hline S2 D & \multicolumn{3}{|c|}{21.19} & 17.74 & 19.47 & \multicolumn{2}{|c|}{20.99} & \multicolumn{2}{|c|}{16.87} & 18.93 & \multicolumn{2}{|c|}{21.09} & \multicolumn{2}{|c|}{17.31} & 19.20 \\
\hline Mean & & 21.94 & & 18.30 & 20.12 & 21 & & & & 19.23 & & & & & 19.68 \\
\hline D1 & & 23.68 & & 19.67 & 21.67 & & & & & 20.65 & & & & & 21.16 \\
\hline D2 & & 21.74 & & 18.68 & 20.21 & & & & & 19.55 & & & & & 19.88 \\
\hline Mean & & 22.71 & & 19.17 & 20.94 & & & & & 20.10 & & & & & 20.52 \\
\hline Comparison & $\mathrm{S}$ & $\mathbf{T}$ & D & L & $\mathrm{S} \times \mathrm{T}$ & $\mathrm{S} \times \mathbf{D}$ & $\mathrm{S} \times \mathrm{L}$ & $T \times D$ & $T \times L$ & $\mathbf{D} \times \mathbf{L}$ & $S \times T \times D$ & $\mathbf{S} \times \mathbf{T} \times \mathbf{L}$ & $\mathrm{S} \times \mathrm{D} \times \mathrm{L}$ & $T \times \mathbf{D} \times \mathbf{L}$ & $\mathrm{S} \times \mathrm{T} \times \mathbf{D} \times \mathbf{L}$ \\
\hline SEm \pm & 0.23 & 0.23 & 0.23 & 0.23 & 0.33 & 0.33 & 0.33 & 0.33 & 0.33 & 0.33 & 0.46 & 0.31 & 0.46 & 0.46 & 0.65 \\
\hline $\mathrm{CD}$ at $5 \%$ & 0.67 & 0.67 & 0.67 & 0.67 & 0.94 & 0.94 & 0.94 & 0.94 & 0.94 & 0.94 & 1.33 & 0.89 & 1.33 & 1.33 & 1.88 \\
\hline
\end{tabular}

Note: S1: Winter season D1: Depth at 5cm L1:Agro-forestry Bengaluru T1:Simarouba glauca

S2: Summer season D2: Depth at 10cm L2: Bio-fuel park Hassan T2:Calophyllum inophyllum 
Table 6: Available Soil Sulphur (ppm) at 60 Days after Leaf Litter Decomposition as Influenced by Soil Depth, Seasons and Locations of Trees under Agro Forestry System

\begin{tabular}{|c|c|c|c|c|c|c|c|c|c|c|c|c|c|c|c|}
\hline \multirow[t]{2}{*}{ Details } & \multicolumn{5}{|c|}{$\mathrm{L}_{1}$} & \multicolumn{5}{|c|}{$\mathrm{L}_{2}$} & \multicolumn{5}{|c|}{ Pooled } \\
\hline & \multicolumn{3}{|c|}{$\mathrm{Tl}$} & $\mathrm{T} 2$ & Mean & \multicolumn{2}{|c|}{$\mathrm{Tl}$} & \multicolumn{2}{|c|}{$\mathrm{T} 2$} & Mean & \multicolumn{2}{|c|}{$\mathrm{Tl}$} & \multicolumn{2}{|c|}{$\mathrm{T} 2$} & Mean \\
\hline S1D1 & \multicolumn{3}{|c|}{28.71} & 22.87 & 25.79 & \multicolumn{2}{|c|}{27.35} & \multicolumn{2}{|c|}{21.08} & 24.22 & \multicolumn{2}{|c|}{28.03} & \multicolumn{2}{|c|}{21.98} & 25.00 \\
\hline S1D2 & \multicolumn{3}{|c|}{27.04} & 21.94 & 24.49 & \multicolumn{2}{|c|}{26.83} & \multicolumn{2}{|c|}{19.80} & 23.32 & \multicolumn{2}{|c|}{26.94} & \multicolumn{2}{|c|}{20.87} & 23.90 \\
\hline Mean & \multicolumn{3}{|c|}{27.88} & 22.41 & 25.14 & \multicolumn{2}{|c|}{27.09} & \multicolumn{2}{|c|}{20.44} & 23.77 & \multicolumn{2}{|c|}{27.48} & \multicolumn{2}{|c|}{21.42} & 24.45 \\
\hline S2D1 & \multicolumn{3}{|c|}{26.21} & 20.77 & 23.49 & \multicolumn{2}{|c|}{25.69} & \multicolumn{2}{|c|}{19.62} & 22.66 & \multicolumn{2}{|c|}{25.95} & \multicolumn{2}{|c|}{20.20} & 23.07 \\
\hline S2D & \multicolumn{3}{|c|}{24.01} & 19.49 & 21.75 & \multicolumn{2}{|c|}{23.56} & \multicolumn{2}{|c|}{18.79} & 21.18 & \multicolumn{2}{|c|}{23.79} & \multicolumn{2}{|c|}{19.14} & 21.46 \\
\hline Mean & & 25.11 & & 20.13 & 22.62 & 24 & & & & 21.92 & & & & & 22.27 \\
\hline D1 & & 27.46 & & 21.82 & 24.64 & 26 & & & & 23.44 & & & & & 24.04 \\
\hline D2 & & 25.53 & & 20.72 & 23.12 & 25 & & & & 22.25 & & & & & 22.68 \\
\hline Mean & & 26.49 & & 21.27 & 23.88 & & & & & 22.84 & & & & & 23.36 \\
\hline Comparison & $S$ & $\mathrm{~T}$ & D & L & $S \times T$ & $S \times D$ & $\mathrm{~S} \times \mathrm{L}$ & $T \times D$ & $\mathrm{~T} \times \mathrm{L}$ & $\mathrm{D} \times \mathrm{L}$ & $S \times T \times D$ & SXTXL & $\mathrm{S} \times \mathrm{D} \times \mathrm{L}$ & $T \times D \times L$ & SXTXDXL \\
\hline SEm \pm & 0.36 & 0.36 & 0.36 & 0.36 & 0.51 & 0.51 & 0.51 & 0.51 & 0.51 & 0.51 & 0.71 & 0.20 & 0.71 & 0.71 & 1.01 \\
\hline $\mathrm{CD}$ at $5 \%$ & 1.03 & 1.03 & 1.03 & 1.03 & 1.46 & 1.46 & 1.46 & 1.46 & 1.46 & 1.46 & 2.06 & 0.57 & 2.06 & 2.06 & 2.91 \\
\hline
\end{tabular}

Note: S1: Winter season D1: Depth at 5cm L1:Agro-forestry Bengaluru T1:Simarouba glauca

S2: Summer season D2: Depth at 10cm L2: Bio-fuel park Hassan T2:Calophyllum inophyllum

Table 7: Available Soil Sulphur (ppm) at 90 Days after Leaf Litter Decomposition as Influenced by Soil Depth, Seasons and Locations of Trees under Agro Forestry System

\begin{tabular}{|c|c|c|c|c|c|c|c|c|c|c|c|c|c|c|c|}
\hline \multirow[t]{2}{*}{ Details } & \multicolumn{5}{|c|}{$\mathrm{L}_{1}$} & \multicolumn{5}{|c|}{$\mathrm{L}_{2}$} & \multicolumn{5}{|c|}{ Pooled } \\
\hline & \multicolumn{3}{|c|}{$\mathrm{Tl}$} & $\mathrm{T} 2$ & Mean & \multicolumn{2}{|c|}{$\mathrm{Tl}$} & \multicolumn{2}{|c|}{ T2 } & Mean & \multicolumn{2}{|c|}{$\mathrm{Tl}$} & \multicolumn{2}{|c|}{ T2 } & Mean \\
\hline S1D1 & \multicolumn{3}{|c|}{32.78} & 27.06 & 29.92 & \multicolumn{2}{|c|}{31.39} & \multicolumn{2}{|c|}{26.11} & 28.75 & \multicolumn{2}{|c|}{32.09} & \multicolumn{2}{|c|}{26.59} & 29.34 \\
\hline S1D2 & \multicolumn{3}{|c|}{30.42} & 25.20 & 27.81 & \multicolumn{2}{|c|}{29.90} & \multicolumn{2}{|c|}{24.94} & 27.42 & \multicolumn{2}{|c|}{30.16} & \multicolumn{2}{|c|}{25.07} & 27.62 \\
\hline Mean & \multicolumn{3}{|c|}{31.60} & 26.13 & 28.87 & \multicolumn{2}{|c|}{30.65} & \multicolumn{2}{|c|}{25.53} & 28.09 & \multicolumn{2}{|c|}{31.12} & \multicolumn{2}{|c|}{25.83} & 28.48 \\
\hline S2D1 & \multicolumn{3}{|c|}{29.07} & 23.61 & 26.34 & \multicolumn{2}{|c|}{28.86} & \multicolumn{2}{|c|}{21.44} & 25.15 & \multicolumn{2}{|c|}{28.97} & \multicolumn{2}{|c|}{22.53} & 25.75 \\
\hline S2D & \multicolumn{3}{|c|}{28.00} & 22.82 & 25.41 & \multicolumn{2}{|c|}{27.74} & \multicolumn{2}{|c|}{20.78} & 24.26 & \multicolumn{2}{|c|}{27.87} & \multicolumn{2}{|c|}{21.80} & 24.84 \\
\hline Mean & & 28.54 & & 23.22 & 25.88 & 28 & & & & 24.71 & & & 22 & & 25.29 \\
\hline $\mathrm{D} 1$ & & 30.93 & & 25.34 & 28.13 & 30 & & & & 26.95 & & & 24 & & 27.54 \\
\hline D2 & & 29.21 & & 24.01 & 26.61 & 28 & & & & 25.84 & & & 23 & & 26.23 \\
\hline Mean & & 30.07 & & 24.67 & 27.37 & 29 & & & & 26.40 & & & 24 & & 26.88 \\
\hline Comparison & $\mathrm{S}$ & $\mathrm{T}$ & $\mathrm{D}$ & $\mathrm{L}$ & $\mathrm{S} \times \mathrm{T}$ & SXD & $\mathrm{S} \times \mathrm{L}$ & $\mathrm{T} \times \mathrm{D}$ & $\mathrm{T} \times \mathrm{L}$ & $\mathrm{D} \times \mathrm{L}$ & $S \times T \times D$ & $\mathrm{~S} \times \mathrm{T} \times \mathrm{L}$ & $S \times D \times L$ & $\mathrm{~T} \times \mathrm{D} \times \mathrm{L}$ & SXTXDXL \\
\hline SEm \pm & 0.22 & 0.22 & 0.22 & 0.22 & 0.31 & 0.31 & 0.31 & 0.31 & 0.31 & 0.31 & 0.44 & 0.01 & 0.44 & 0.44 & 0.62 \\
\hline $\mathrm{CD}$ at $5 \%$ & 0.64 & 0.64 & 0.64 & 0.64 & 0.90 & 0.90 & 0.90 & 0.90 & 0.90 & 0.90 & 1.27 & 0.02 & 1.27 & 1.27 & 1.80 \\
\hline
\end{tabular}

Note: S1: Winter season D1: Depth at 5cm L1:Agro-forestry Bengaluru T1:Simarouba glauca

S2: Summer season D2: Depth at 10cm L2: Bio-fuel park Hassan T2:Calophyllum inophyllum

\section{REFERENCES}

1. BAKER, T. G. AND ATTIWILL, P. M., 1985, Loss of organic matter and elements from decomposing litter of Eucalyptus obliqua L. Herit and Pinus radiata D. Don. Australian Forest Research, 15: 309-319.

2. BRAY,R. H. AND KURTZ, L. T., 1945, Determination of total, organic and available forms of phosphorus in soils. Soil Sci., 59: 39-45.

3. FACELLI, J. M. AND PICKETT, S. T. A., 1991, Plant litter: Its dynamics and effects on plant community structure. Bot. Rev., 57: $1-32$.

4. JACKSON, M. L., 1973, Soil Chemical Analysis. Prentice Hall of India (Pvt.) Ltd., New Delhi.

5. RANGASWAMY, R., 2010, A text book of agricultural statistics. New ageInternational Publishers, New Delhi., pp: 1-537 
6. WILLIAMS, C.H. AND STEINBERGS, A., 1959, Soil sulphur fractions as chemical indices of available sulphur in some Australian soils.Australian Journal ofAgricultural Research.,10:340-352.

7. XU, X. AND HIRATA, E., 2005, Decomposition patterns of leaf litter of seven common canopy species in a subtropical forest: $N$ and $P$ dynamics. Plant Soil, 273: 279-289. 